\title{
Image digitalization as a tool for processing experimental data of crack width of concrete
}

Réka Anna Nagy Civil engineer (MSc, Budapest University of Technology and Economics), PhD candidate at Department of Construction Materials and Engineering Geology. Main fields of interest: cracking of concrete, durability of structural materials, use of FRP reinforcements for concrete structures.

RÉKA NAGY - MSc (CE), PhD candidate, BME Dept. of Construction Materials and Engineering Geology

- nagy.reka@epito.bme.hu

Érkezett: 2014. 11. 05. - Received: 05. 11. 2014. - http://dx.doi.org/10.14382/epitoanyag-jsbcm.2014.22

\begin{abstract}
The present paper introduces a new approach for the continuous measurement of the width of structural cracks within the concrete cover by image digitalizing and digital image processing methods. It is demonstrated that crack width measurement may hold reading error if an operator reads the crack widths by hand microscope or by digital microscope at locations chosen by subjective means. It is highlighted that the tortuosity of structural cracks in concrete can be mapped and described only by detailed image processing methods.

Keywords: concrete, crack width, digital image processing, tortuosity
\end{abstract}

\section{Introduction}

Mechanical and durability performance of reinforced concrete structures is considerably influenced by structural cracks formed during flexural or direct tensile loading. Structural cracks have an effect both to serviceability and load bearing capacity. The increase of deformations due to the decreased stiffness at a cracked section may result unacceptable appearance or changing the static system. The increased permeability of cracked concrete may result advanced ingress of $\mathrm{CO}_{2}$ and aqueous solutions towards the steel reinforcing bars, increasing the risk of corrosion. Water leakage can result unacceptable functional or aesthetical condition. Results of structural cracking can reduce the service life of structures, therefore, several literature studies are available in the field. No general conclusion, however, is available on the role of structural cracking and durability; the only observations are that the corrosion of reinforcement is independent from the surface crack widths and the corrosion of reinforcement is accelerated in the presence of chloride ions [1-7].

The width of a structural crack at the surface of the reinforcement depends primarily on the diameter of the reinforcing bar, the surface configuration of the reinforcing bar, the Young's modulus of the reinforcing bar, the strength of concrete, the magnitude of the effective concrete area in tension and the stress in the reinforcing bar. This latter one can be considered to be the most important influencing parameter. The width of a structural crack within the concrete cover is, however, different from that of measured at the surface of the structural element [8-11]. Comprehensive analysis of this behaviour is a gap in the technical literature.

\section{Significance}

Deformations of concrete in the vicinity of cracks are developed as a result of a very complex phenomenon of the composite material. It is the reason why no model is available in the technical literature that would allow conversion of crack widths at the surface of the reinforcing bars into the crack widths that appear on the outer surface of the concrete elements.
Only limited number of publications is available in the technical literature that tried to analyse the crack width along the concrete cover and tried to determine what type of relationship could be supposed between the crack widths at the surface of the reinforcing bars and that of on the outer surface of concrete structures [8-12]. Based on the available literature data it can be concluded that some kind of proportionality is possible to be found between the crack width at the surface of the reinforcing bars and that of on the outer surface on the concrete structure (emphasizing that the validity of the published results are restricted to the testing conditions). The published range is:

$$
\mathrm{w}_{\text {outer surface }} / \mathrm{w}_{\text {reinforcement surface }}=1.1 \text { to } 7.7
$$

It should be emphasized that the ratio depends on the magnitude of concrete cover, the load level (steel stress), the strength of concrete, the Young's modulus of concrete, the surface configuration of the reinforcing bar.

\section{Previous studies}

Borosnyói and Snóbli (2010) have studied reinforced concrete tie elements of $120 \times 120 \mathrm{~mm}$ cross section and $900 \mathrm{~mm}$ length reinforced with one single $\varnothing 20 \mathrm{~mm}$ deformed steel reinforcing bar placed either concentrically or eccentrically [13]. Concrete covers were 20, 40, 60, $80 \mathrm{~mm}$ for the eccentric specimens and $50 \mathrm{~mm}$ for the concentric specimens.

Injection of structural cracks was carried out from the surface of the members and the detailed mapping of the internal crack width variation within the concrete cover was studied. Epoxy resin was used for the injection. The cracks were maintained in their original, loaded position and the axial load was released only after the resin was allowed to set. Surface crack pattern and surface crack widths were recorded and then the specimens were cut open by a high speed diamond saw. Crack widths were recorded by a hand microscope (scale of $0.01 \mathrm{~mm}$ ) at every $2 \mathrm{~mm}$ along each crack. Present paper gives a comprehensive analysis of the same test specimens that were used in [13]. 

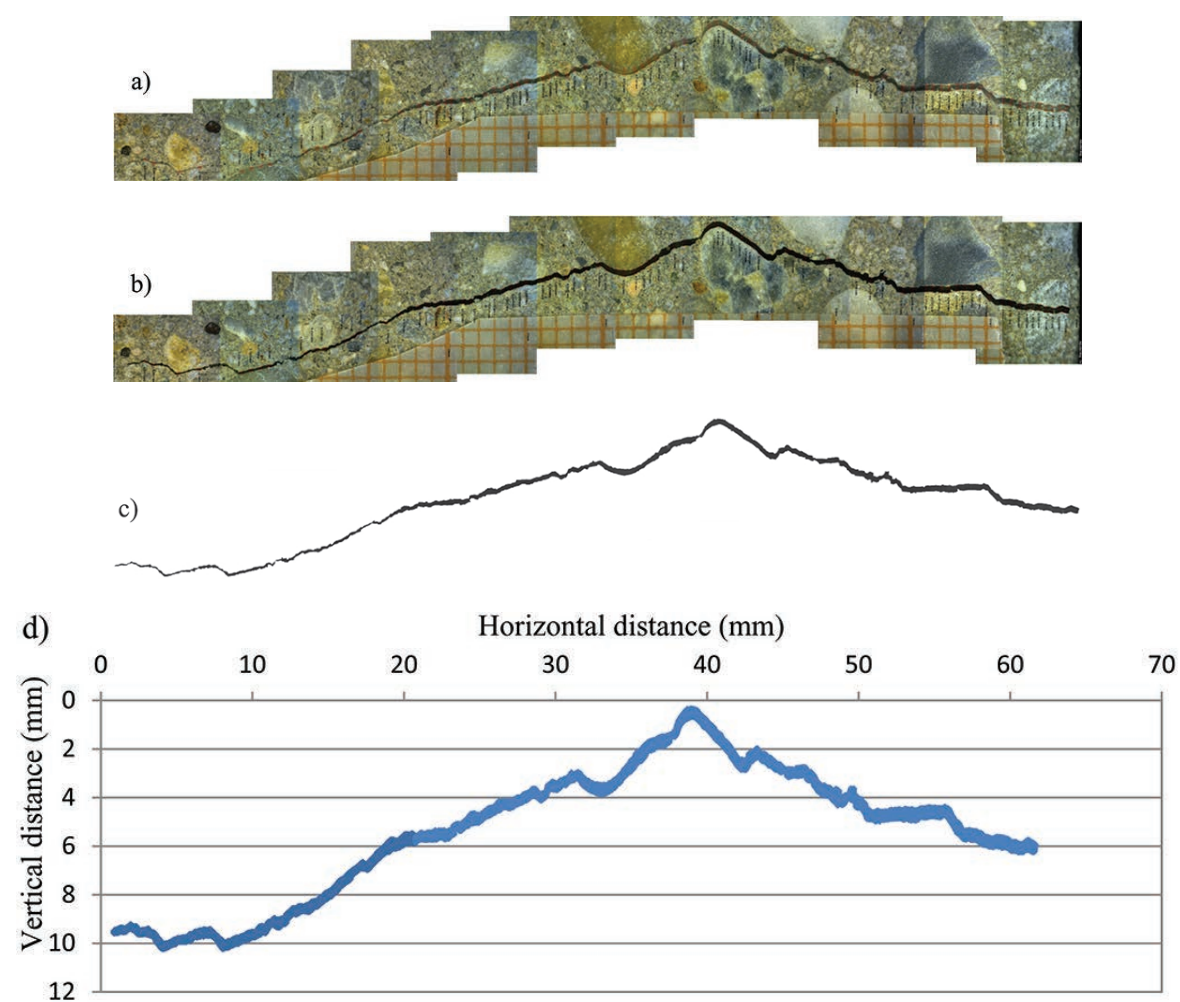

Fig. 1. Steps of digitalization a) original image b) crack after contrast adjustment c) separated crack d) crack drawn by pixel coordinates

1. ábra Digitális képfeldolgozás lépései a) az eredeti felvétel b) a repedés a kontraszt kiemelése után c) az elkülönített repedés d) a pixel koordináták alapján megrajzolt repedés

\section{Refining possibilities}

The drawback of the classic optical crack width measurement method is that the read values depend on the person's sensory sensitivity who carries out the measurement and all specimens are needed to be stored if more data would like to be gathered for further analysis.

The images of the cracks formed during the laboratory tests detailed in [13] were scanned by the author with a digital microscope. Crack widths were chosen to be read at every $0.5 \mathrm{~mm}$ along their length with the data analyzing software provided with the microscope. Details of the digital readings and analysis are given elsewhere [14]. The images of the cracks, therefore, became available as digital images to be processed later and more data can be obtained compared to the hand microscope recordings. It can be emphasized, however, that the accuracy of the scanned data analysis with the use of commercial software still depends on the person's subjective decisions during the readings when the location of points for measurements are chosen. If one could provide a more comprehensive analysis that is free of bias then a full length digital processing of the digital images of the crack width recordings should be developed.

\section{Digitalizing}

Describing the variation of crack width within the concrete cover can help to explain the possible correlation between surface crack width and corrosion, if any. Therefore, it is needed to find a method to process experimental data that is objective and repeatable in the survey of crack width variation along cracks.
Digital image processing provides the possibility of pixeldepth analysis of digital images. The first task during digital processing of the scanned images is the contrast adjustment so that the points within the crack can be represented in high contrast and can be differentiated from the surroundings. Fig. 1.a indicates the original scanned images and Fig. 1.b shows the picture of the crack after contrast adjustment. Then the crack is separated from the surroundings (Fig. 1.c) and the image is subjected to numerical analysis to find coordinates of the points along the crack. As a result, the crack can be described by pixel coordinates (Fig. 1.d) and numerical calculations can be carried out.

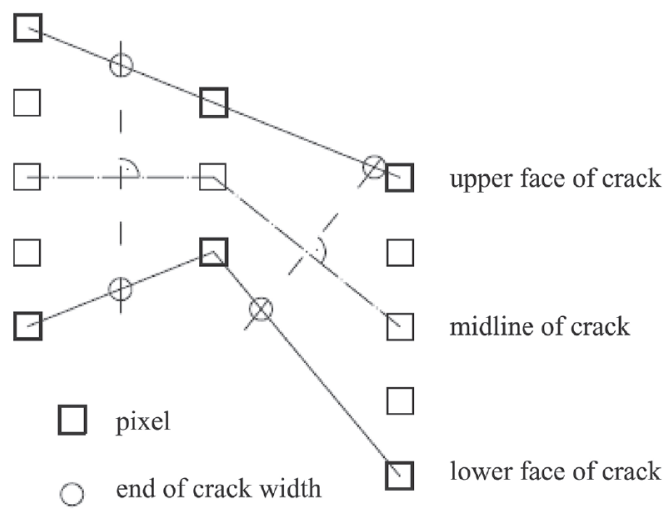

Fig. 2. Defining crack width - schematic diagram

2. ábra A repedéstágasság leolvasás elvi sémája

The crack width is defined as the distance between the crack faces along a line perpendicular to the midline of the crack, as represented in Fig. 2. In order to calculate crack width, the 
coordinates of the pixels of the crack faces are needed to be determined first. Then the position of the pixels corresponding to the midline can be defined and the perpendicular lines can be taken at arbitrary frequency. Coordinates define splines, along which the position of the perpendiculars (on the midline) and the intersection points (on the crack faces) can be determined outside the original pixels as well.
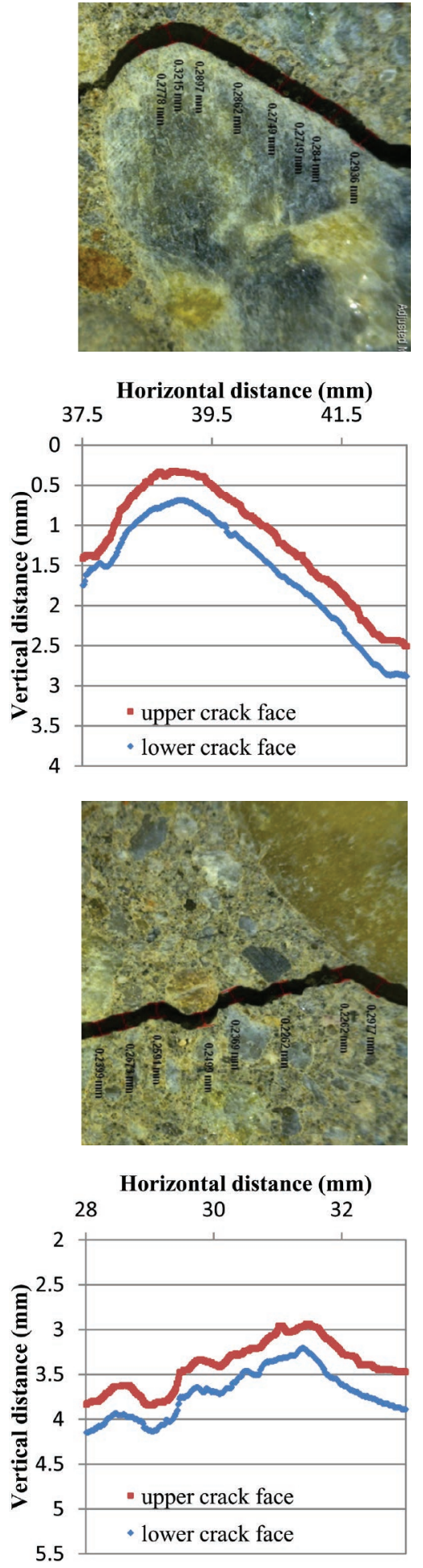

Fig. 3. Scanned images of cracks together with the corresponding crack face coordinates

3. ábra Repedések szkennelt képe és a repedésszélek koordinátapontjai
Fig. 3 indicates scanned images for two sections of cracks together with arbitrary crack width readings that are compared to the digitalized pixel coordinates of upper and lower crack faces. It can be realized that the coordinates of upper and lower crack faces are well defined and indicate the possibility of crack width measurement with a suitable numerical approach.

\section{Results and analysis}

The crack width measurement results obtained by numerical analysis of the digitalized crack width pixel data for an arbitrary crack are presented in Fig. 4 together with the recordings of the same crack with the methods described in Chapter 3 and 4. The values are in good accordance for all the three measuring methods. It can be realized that the crack width values obtained by the introduced numerical analysis of the digitalized crack width pixel data show more scattered behaviour. It is attributed to the fact that the number of readings was different for the three different methods.

During recording of crack widths by hand microscope or by the commercial analysis software of the digital microscope one makes readings at fewer points and human eye chooses measurement points that are easy to read while the results of the numerical analysis of the digitalized crack width pixel data show the real values of crack width with all its unevenness.

It can be also seen that the sensitivity of human eye reading is very much limited at the range of $0.01 \mathrm{~mm}$ that was the scale of the hand microscope used in [13] - human eye notoriously reads lower crack width values than the real magnitude.

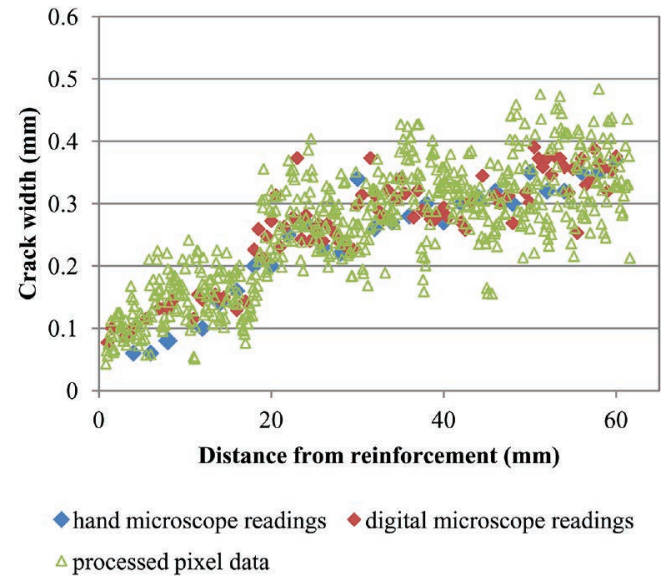

Fig. 4. Comparison of crack widths measured with hand microscope, digital microscope readings and image processing

4. ábra Repedéstágasság összehasonlítása kézi mikroszkóppal, digitalis mikroszkóppal történö leolvasás és pixeles feldolgozás esetében

Based on the findings of Fig. 4, it is also possible to estimate the relative error and precision of the crack width measurements by the three different methods. Fig. 5 indicates the differences between the crack width readings for hand microscope vs. processed pixel data, digital microscope readings vs. processed pixel data and hand vs. digital microscope methods, respectively. Relative error can be represented as the average of the differences in the measurements while relative precision can be represented as the standard deviation of the differences in the measurements (Table 1). 


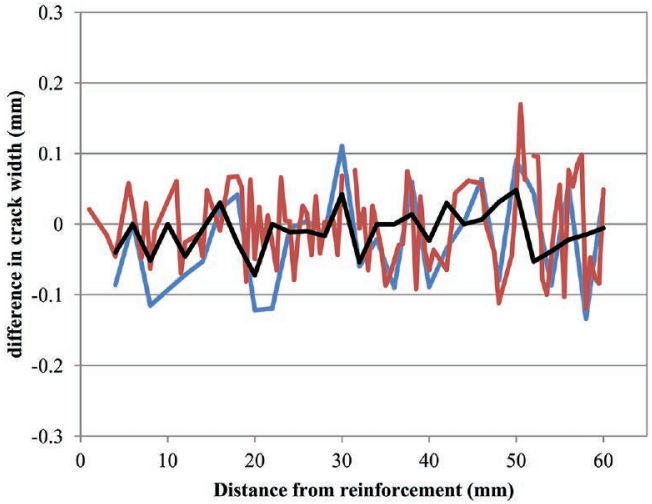

—hand microscope vs. pixel data — digital microscope vs. pixel data

—hand vs. digital microscope

Fig. 5. Comparing the difference of the three methods

5. ábra A három tárgyalt módszer különbségeinek összehasonlítása

\begin{tabular}{lcc} 
Crack width difference $(\mathbf{m m}):$ & average & standard deviation \\
\hline hand microscope - pixel data & -0.023 & 0.0702 \\
\hline digital microscope - pixel data & -0.002 & 0.0598 \\
\hline hand - digital microscope & -0.009 & 0.0293
\end{tabular}

Table 1. Difference of crack widths by the three methods

1. táblázat Repedéstágasság különbség a három módszerrel

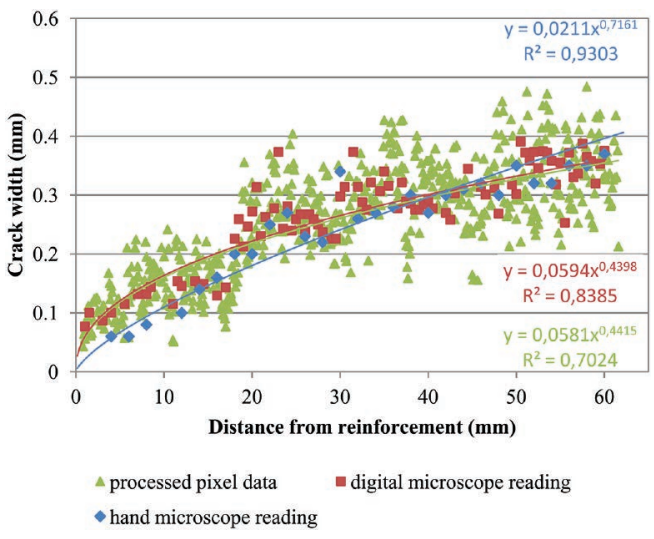

Fig. 6. Comparison of crack widths measured with hand microscope, digital microscope readings and image processing (trend analysis)

6. ábra Repedéstágasság összehasonlitása kézi mikroszkóppal, digitalis mikroszkóppal történő leolvasás és pixeles feldolgozás esetében (trendvonalak bemutatásával)

Digital microscope readings and the values obtained by image processing show low relative error compared to each other while hand microscope readings and the processed data show higher relative error compared to each other. The difference between the calculated relative errors is in the order of about ten (Table 1). Expectedly, the magnitude of the relative error when comparing hand microscope readings and digital microscope readings is found between the other two values. One reason of the findings may be the instinctive distortion of the reading location selection of human observer when using either hand microscope or digital microscope for the crack width measurements. During such readings the observer has free choice to select the exact reading locations even if a ruler is followed for spacing of readings and may select locations which are considered to provide kind of representative values for the crack width. The less is the number of the readings, the higher value of the error may be resulted. Another possible reason can be the lack of calibration of the hand microscope device that results bias of the measured values. The third reason is the intrinsic driving force of the observations that is the real tortuosity of the crack. The more sophisticated is the survey of the crack geometry, the more detailed information becomes available on tortuosity. It can be realized from the present study that changing the number of observations has a considerable influence on the visibility of tortuosity of the crack (Fig. 6). Future numerical analysis of digitalized crack width pixel data is needed to see the possibilities of modelling crack tortuosity in concrete since tortuosity is an important parameter of permeability of cracked concrete.

\section{Conclusions}

The width of structural cracks within the concrete cover is different from that of measured at the surface of the structural elements. Only limited number of publications is available in the technical literature that tried to analyse the crack width along the concrete cover. Experimental results of previous study by Borosnyói and Snóbli [13] is analysed further in this paper after digital scanning of the surface of the same specimens and digital image processing of the obtained data. The proposed method is demonstrated to be useful for detailed survey and analysis of crack widths within the concrete cover. It is highlighted that human eye sensory sensitivity and subjective readings of human observer hold reading error. It is shown that changing the number of observations has a considerable influence on the visibility of tortuosity of structural cracks of concrete.

References

[1] Beeby, A. (1983): Cracking, cover and corrosion of reinforcement, Concrete International, Vol. 5, No. 2, 1983, pp. 35-40.

[2] Darwin, D. (1985): Debate - Crack Width, Cover, and Corrosion. Concrete International, Vol. 7, No. 5, 1985, p. 20-35.

[3] Berke, N. S. - Dellaire, M. P. - Hicks, M. C. - Hoopes, R. J. (1993): Corrosion of Steel in Cracked Concrete. Corrosion, Vol. 49, No. 11, 1993, p. 934-943.

http://dx.doi.org/10.5006/1.3316020

[4] Jacobsen, S. - Marchand, J. - Boisvert, L. (1996): Effect of cracking and healing on chloride Transport in OPC concrete. Cement and Concrete Research, Vol. 26, No. 6, 1996, pp. 869-881.

http://dx.doi.org/10.1016/0008-8846(96)00072-5

[5] Schiessl, P. - Raupach, M. (1997): Laboratory studies and calculations on the influence of crack width on chloride-induced corrosion in concrete, ACI Materials Journal, Vol. 94, No. 1, 1997, pp. 56-61. http://dx.doi.org/10.14359/285

[6] Otsuki, N. - Miyazato, S. - Diola, N. - Suzuki, H. (2000): Influences of bending crack and water-cement ratio on chloride-induced corrosion of main reinforcing bars and stirrups, ACI Materials Journal, Vol. 97, No. 4, 2000, pp. 454-464.

http://dx.doi.org/10.14359/7410

[7] Vidal, T. - Castel, A. - Francois, R. (2004): Analyzing crack width to predict corrosion in reinforced concrete. Cement and Concrete Research, Vol. 34, 2004, pp. 165-174.

http://dx.doi.org/10.1016/S0008-8846(03)00246-1

[8] Broms, B. (1965): Crack width and crack spacing in reinforced concrete members, ACI Journal, Vol. 62, No. 10, 1965, pp. 1237-1256. http://dx.doi.org/10.14359/7742 
[9] Husain, S. I. - Ferguson, P. M. (1968): Flexural Crack Widths at the Bars in Reinforced Concrete Beams. Center for Highway Research, The University of Texas at Austin, Research Report No. 102,1F, 1968.

[10] Tammo, K. - Thelandersson, S. (2006): Crack opening near reinforcement bars in concrete structures. Structural Concrete, Vol.7, No. 4, 2006, pp. 137-143. http://dx.doi.org/10.1680/stco.2006.7.4.137

[11] Yannopoulos, P. J. (1989): Variation of concrete crack widths through the concrete cover to reinforcement. Magazine of Concrete Research, Vol. 41, No. 147,1989 , pp. 63-68.

http://dx.doi.org/10.1680/macr.1989.41.147.63

[12] Borosnyói, A. (2010): Bond of carbon fibre reinforced polymer (CFRP) prestressing tendons in concrete. Multi-parameter laboratory studies, Épités - Épitészettudomány, Vol. 38. No. 1-2. 2010, pp. 95-120. (in Hungarian) http://dx.doi.org/10.1556/EpTud.38.2010.1-2.5

[13] Borosnyói A. - Snóbli I. (2010): Crack width variation within the concrete cover of reinforced concrete members, Épitöanyag-JSBCM, Vol. 62, No. 3., pp. 70-74.

http://dx.doi.org/10.14382/epitoanyag-jsbcm.2010.14

[14] Nagy, R. (2013): Structural cracking of reinforced concrete members, Second Conference of Junior Researchers in Civil Engineering, 17-18 June 2013, Budapest, Hungary, pp. 136-141.

https://www.me.bme.hu/doktisk/konf2013/papers/136-141.pdf
Ref.:

Nagy, Réka: Image digitalization as a tool for processing experimental data of crack width of concrete

Épitőanyag - Journal of Silicate Based and Composite Materials, Vol. 66, No. 4 (2014), 120-124. p.

http://dx.doi.org/10.14382/epitoanyag-jsbcm.2014.22

Beton repedéstágasság-mérési eredmények feldolgozása képdigitalizálási eljárással

A cikk bemutat egy új eljárást a beton próbatestek szerkezeti repedéseinek betonfedésen belüli folytonos repedéstágasság mérésére vonatkozóan, amely képdigitalizálási és digitális képfeldolgozási elveket alkalmaz. Bizonyitást nyer, hogy a szabad szemmel, skálázott repedéstágasság-mérô kézi nagyítóval, illetve a digitálisan rögzített képfelvételen az operátor által önkényes helyeken felvett repedéstágasság mérési eredmények mérési hibát hordozhatnak. A cikk rávilágít, hogy a beton szerkezeti repedéseinek tekervényessége csak a bemutatott eljáráshoz hasonlóan részletes képi elemzés útján határozható meg kellô pontossággal.

Kulcsszavak: beton, repedéstágasság, digitalis képfeldolgozás, tekervényesség

\section{EUROPEAN CONCRETE PLATFORM (ECP)}

The European Concrete Platform (ECP) is a European Association which gathers together European branch associations representing the concrete industry and its constituents. The aim of the ECR is to study and promote all aspects of concrete as the material of cholve for sustainable denstruction.

In this-regard, the ECP covers a wide range of topics, ranging from thermal mass and energy efficiency to Euroeodes and fire safety.

The ECP is also involved in several projects and alliances. These include BUILDUP, Fire Safe Europe, the Sustainable Construction Glossary, and Construction Products Europe. For more informationen the issues we cover, please visit the Issues, ECP Positions and Publications sections of our website.
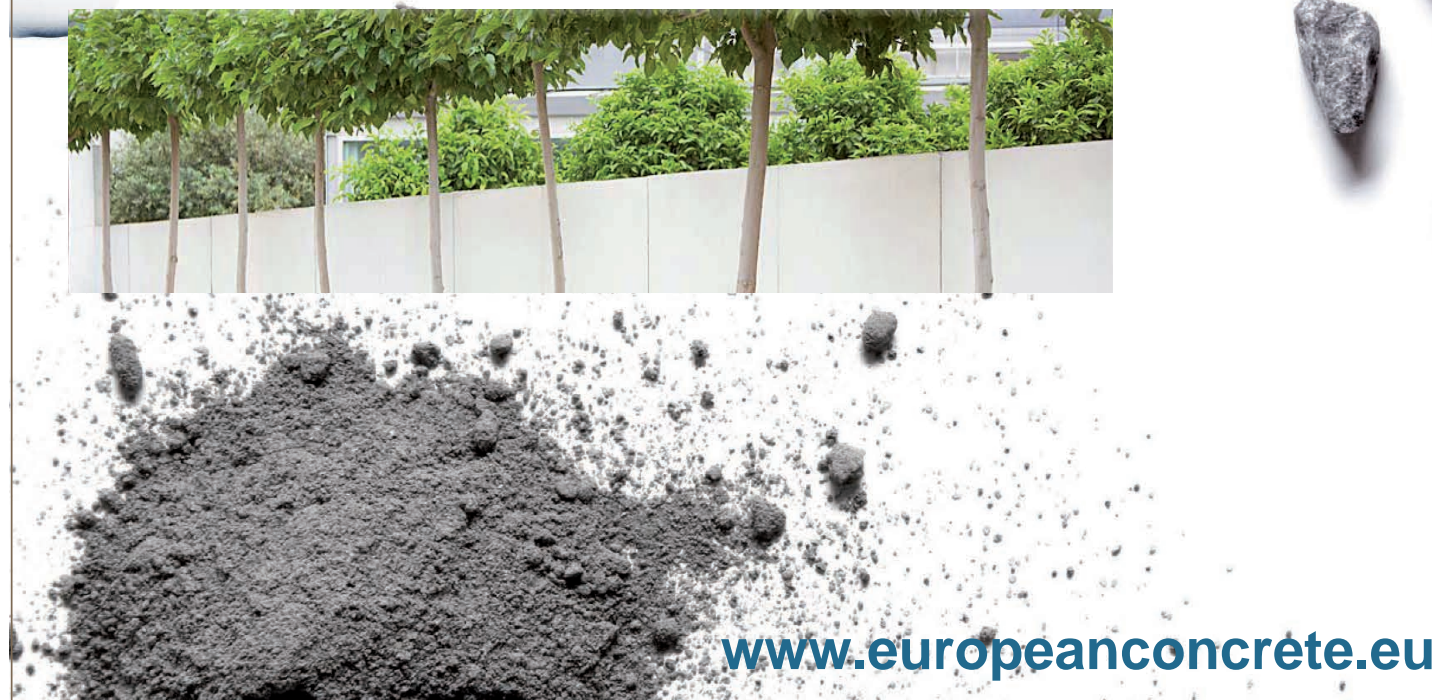